Расулов Р.A., к. т. н., дой. https://scholar.google.com.ua/citations?hl=uk\&user=ILv_DKoAAAAJ

Романенко Р.П., $к$. m. н., дои. https://scholar.google.com.ua/citations?user=cOiZzisAAAAJ\&hl=uk Київський національний торговельно-економічний університет, м. Київ, Україна

\title{
ВПЛИВ КОНСТРУКТИВНОГО ТИПУ КАВОМОЛКИ НА ДИСПЕРСНІСТЬ МЕЛЕНОЇ КАВИ
}

В ресторанних технологіях широко застосовуються різні дисперсні системи: порошки, суспензії, золі, емульсії та ін. Розміри $і$ форми їх частинок - елементів дисперсної фази, має важливе значення для формування смаку та аромату страв, оскільки саме форма та розміри визначають багато властивостей фізичних та технологічних властивостей сипучого продукту [1].

Було проведено порівняння дисперсності помелу кави змеленої на жорнових кавомолках постійної дії: Delonghi KG 520M, Delonghi KG 79, Graef CM 802, та контрольного зразку - на роторній кавомолці періодичної дії - Bosh TSM6A0.13. На всіх жорнових кавомолках виставляли ступінь помелу 7, на кавомолці Bosh TSM6A0.13 мололи протягом $30 \mathrm{c.}$

Дисперсний склад кави визначали по мікрофотографіям на мікроскопі CL PC camera 4.5 та аналізували за допомогою програмного забезпечення «Micro-Measure Tool» [2]. На рис. 1 наведена два фрагменти зображення порошку кави, меленої на роторній та жорновій кавомолках.

Як видно 3 представлених даних, частинки порошку мають неправильну форму, а їх розмір знаходиться у діапазоні 50..250 мкм, тому для характеристики їх дисперсії будемо використовувати середній лінійний розмір [3]. Результати вимірювань, отримані при різних збільшеннях, узагальнювали щодо фракцій частинок. 


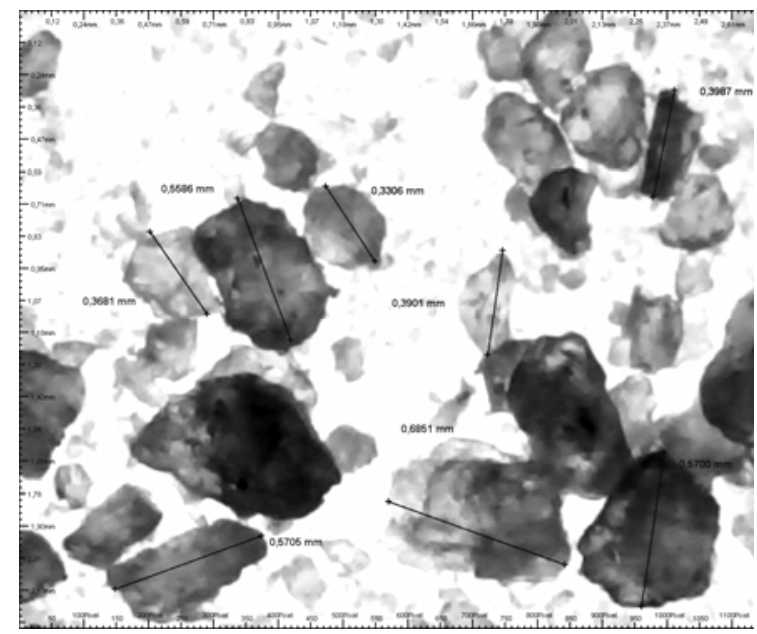

Кавомолка Bosh TSM6A0.13

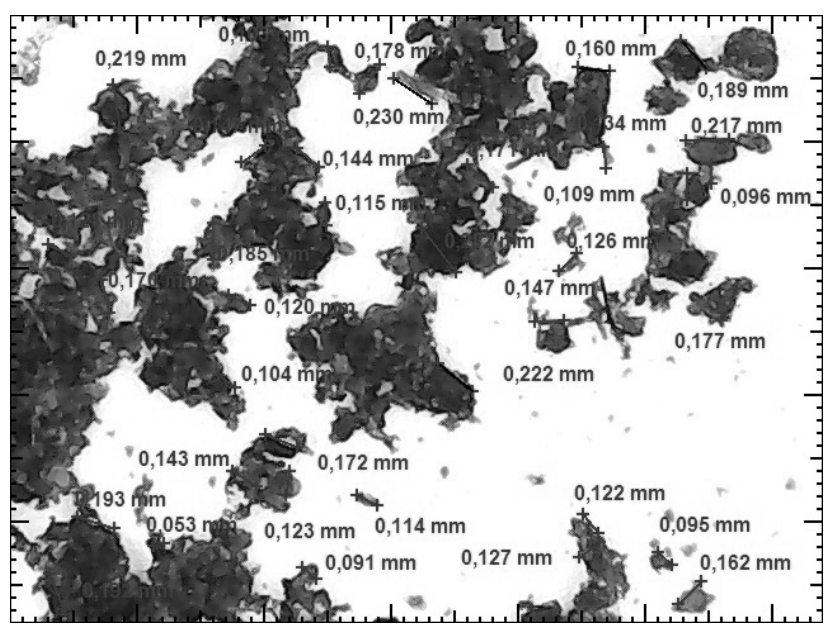

Кавомолка Delonghi KG 520M

Рис. 1. Визначення розмірів частинок кави

Були сформовані криві диференціального розподілу мікрочастинок кави за розмірами (рис. 2).

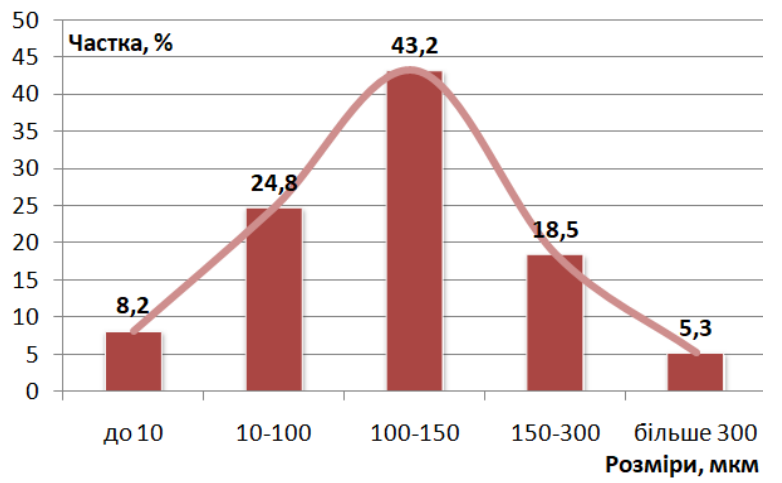

a) Delonghi KG 520M,

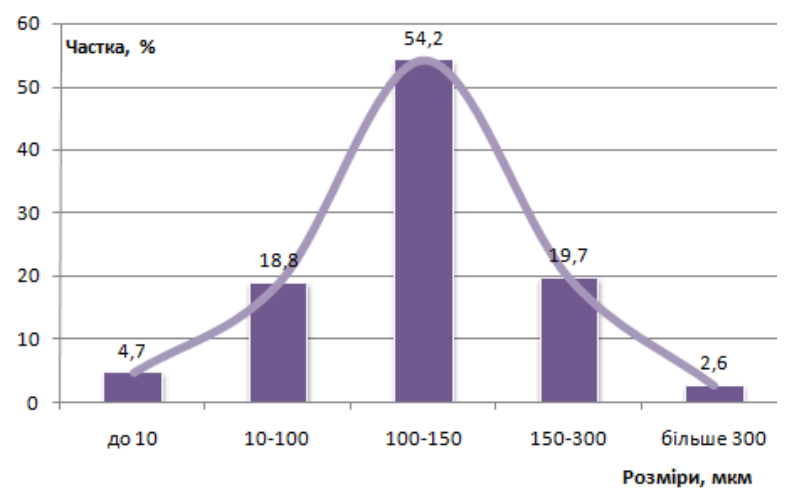

в) Graef CM 802

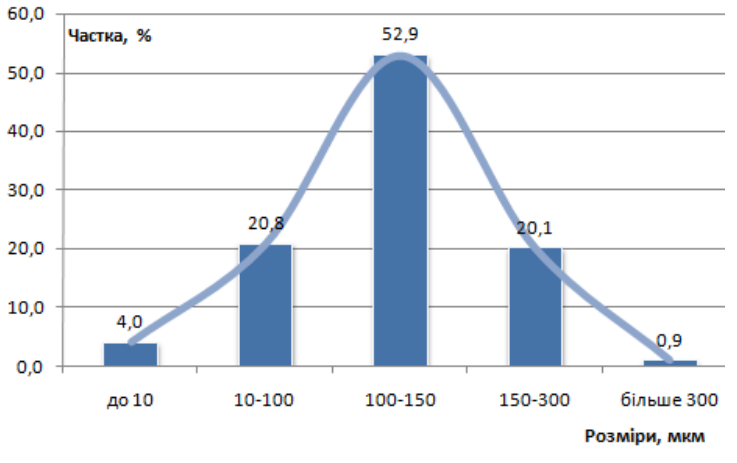

б) Delonghi KG 79

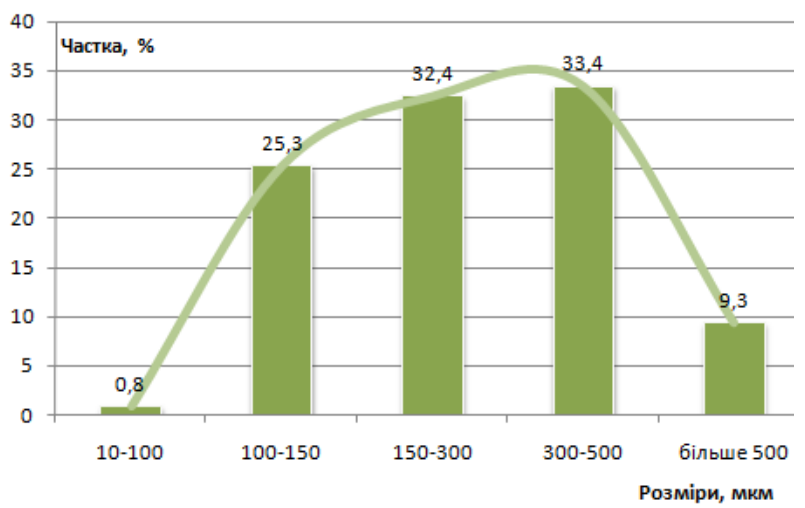

2) Bosh TSM6A0.13

Рис. 2. Криві диференціального розподілу частинок за розмірами у каві меленій 
В цілому, з отриманих даних випливає, що експериментальні крива розподілу часток досліджуваних зразків кави, змеленої на жорнових кавомолках, найкращим чином описуються поліноміальним рівнянням третього ступеня. Розподіл частинок кави, змеленої на роторній кавоварці - поліноміальним рівнянням третього ступеня, і має значно більшу дисперсію результатів.

В цілому, з отриманих даних випливає, що експериментальні крива розподілу часток досліджуваних зразків кави найкращим чином описуються поліноміальним рівнянням третього ступеня.

Встановлено, що дисперсний склад кави змеленої на жорнових кавомолках постійної дії: Delonghi KG 520M, Delonghi KG 79, Graef СМ 802, суттєво відрізняється від кави, змеленій на роторній кавомолці періодичної дії, більшість частинок має розміри у межах $20 \ldots 250$ мкм. Розміри частинок в каві 3 роторної кавоварки має суттєву дисперсію та нерівномірний фракційний склад.

\section{Список бібліографічних посилань}

1. Микроскопические методы определения размеров частиц дисперсных материалов: учеб. пособие / Н. Н. Гаврилова, В. В. Назаров, О.В. Яровая. - М.: РХТУ им. Д. И. Менделеева, 2012. - 52 с.

2. Шаповал С.Л., Романенко Р. П., Форостяна Н. П. Діагностика фізичних властивостей харчових продуктів: монографія. Київ : Київ. нац. торг.-екон. ун-т, 2017. 129 с.

3. O Burdo, V Bandura, A Zykov, I Zozulyak / Using of the wave technologies in intensification processes of heat and mass transfer // EUREKA: Physics and Engineering. - 2017. P. 18-24 